\title{
Physiological responses of Betula pendula Roth growing in polluted areas
}

\author{
Monika Czaja, Anna Kołton, Agnieszka Baran, Ewa Muszyńska, Piotr Muras
}

University of Agriculture in Kraków, Faculty of Biotechnology and Horticulture,

A1. 29 Listopada 54, 31-425, Kraków, Poland,

e-mail: mon.czaja@gmail.com

\begin{abstract}
Plant functioning is affected by drought, extreme temperatures, heavy metal pollution and other unfavorable environmental conditions. High intensity of stress factors can be lethal to sensitive organisms or significantly decrease their condition. Intensification of stress factors is observed especially in urban and industrial areas. During the vegetative season plants purify the air and soil, decrease air temperature, increase humidity and have others psychosociological advantages. It is especially important to monitor growth of plants in areas with high anthropopression. In presented study condition of silver birch (Betula pendula Roth) growing in different stressful environments was investigated. During the research soil parameters such as $\mathrm{pH}, \mathrm{EC}$ and heavy metals content were observed. Chlorophyll $a$ fluorescence, photosynthetic pigment content, phenolic compounds concentration, ability to scavenging DPPH free radical, activity of anti-oxidative enzymes (superoxide dismutase-SOD, peroxidase-POD, catalase-CAT) were examined in the leaves to study plant response to stress factors. Investigated trees showed two types of antioxidative defense systems: with high activity of low molecular weight antioxidants (phenolics) or with high enzymatic antioxidant activity. The most stressed trees showed highest concentration of low molecular weight antioxidants (phenolics).
\end{abstract}

Key words: heavy metal pollution, chlorophyll a fluorescence, Betula pendula, SOD, POD, CAT, DPPH.

\section{Introduction}

Urban and industrial areas are connected with high anthropopression which affects plants growing in those locations. One of the most important and severe stress factor is pollution. It harms ecosystem functioning causing deterioration of plants (Zvereva et al. 2008). Both traffic and industrial exhaust release heavy metals such as: $\mathrm{Cd}, \mathrm{Cr}$, $\mathrm{Pb}, \mathrm{Zn}$ and $\mathrm{Cu}$. Those metals diffuse into air, water and soil, affecting plants and human health. Content of those elements in soil depends on the intensity of its source, distance from the source and also soil parameters (Mmolawa et al. 2011). Anthropogenic dust can be composed from traffic wastes arising due to tire and brake abrasion, fuel and catalytic converters usage but also coal burning and industrial activities. Retention time of toxic heavy metals contained in small fractions of dust is about 250 days long
(Žibret et al. 2013). Heavy metals are not toxic to plants per se, but after their accumulation in plant tissues above established limits. In metallic form (at zero state of oxidation) they are inaccessible to plants. They can be uptaken after change of oxidation state and passed to soil solution as ions (salts or chelates) (Appenroth 2010). Metals bioavailability to plants is different and it depends not only on metal form but also on growth conditions like soil $\mathrm{pH}$, temperature, organic matter and oxygen content (Babula et al. 2008; Nagajyoti et al. 2010). Excess of heavy metal ions in plants can induce reactive oxygen species (ROS) production and cause oxidative stress (Karuppanapandian et al. 2011).

Our experiment at first estimates stress conditions in the environment of investigated plants. Then the plants reactions were examined. To assess photosynthetic apparatus efficiency measurements of chlorophyll $a$ fluorescence 
were used. Fluorescence is widely used to evaluate plant physiological status during stress. Abiotic stresses cause the decrease of photosynthetic efficiency which is connected with chlorophyll $a$ fluorescence increase. When plant is under stressful conditions photosystem II (PSII) may be photoinhibited which leads to increased production of reactive oxygen species due to over-reduction of electron transport (Augustynowicz et al. 2014). Unfavorable conditions of plant growth accelerate plants tissues senescence. One of its first symptoms, beside photosynthesis efficiency loss is a decrease of chlorophyll content (Zhang \& Zhou 2013). Degradation of chlorophylls is connected with the reorganization of the whole chloroplast. Decrease of chloroplast enzymes activity cause the reduction of photosynthetic activity. Products of such degradations are translocated to other parts of plants where are used or stored until the end of unfavorable condition (Hörtensteiner \& Feller 2002). Another process during stress-induced senescence, beside chlorophyll and protein breakdown, is oxidative stress induction. Plant reaction to such stress is immediate and includes different mechanisms of defense. One of them is activation of anti-oxidative enzymes such as superoxide dismutase (SOD), peroxidase (POD), catalase (CAT). Other way includes accumulation of phenolic compounds which can act as antioxidants (Carvalho et al. 2012; Chen et al. 2006). We also evaluated free radical scavenging activity of leaf extracts against the DPPH free radical (2,2-diphenyl-1-picrylhydrazyl) to estimate anti-oxidative potential of the investigated plants. Silver birch (Betula pendula) is a tree species known for its recultivation usefulness. Previous researches showed that birch trees uptake and accumulate $\mathrm{Cd}, \mathrm{Pb}, \mathrm{Zn}$ in their organs. The ability to coping with stress of heavy metal pollution and other unfavorable growth conditions are known although the details of its survival are not well known (Hanus-Fajerska \& Ciarkowska 2010; Muszyńska et al. 2013).

The aim of the study was (1) to investigate soil properties in places of Betula pendula growth and (2) to research physiological responses of those trees to stress factors (determine if the antioxidative reaction is based on low molecular weight antioxidants or enzymatic ones).

\section{Material and methods}

Mature trees (up to 20 years old) of silver birch (Betula pendula Roth) were investigated in six experimental sites chosen in urban and industrial areas.

Urban 1 - Home garden in Cracow located about $1 \mathrm{~km}$ from medium-traffic road (U1).

Urban 2 - Recultivated area of Solvay Sodium Factory in Cracow inactive for 25 years (U2).

Urban 3 - Greenbelt along heavy traffic road in Cracow (U3).
Industrial 4 - Old calamine waste heap obtained after mining and metallurgical engineering in $19^{\text {th }}$ century, located in Bukowno near Olkusz (Southern Poland) and forested due to natural succession (I4).

Industrial 5 - The settling pond shelf formed from material disposed after zinc and lead ores processes which continue to this day (I5).

Industrial 6 - State Forests area recultivated by human activity a few years ago, on areas used in zinc and lead ores processes (I6).

In every location at least three plants were examined. Leaves were taken in the morning hours, from every cardinal direction, about 50 leaves from each location, from up to $3 \mathrm{~m}$ height. Leaves were collected at the end of July 2014. The term of the research was chosen to enable collection of fully grown, mature leaves, after they intensive growth phase end but before the senescence period. To our study we have chosen only healthy leaves, without any damages or disease symptoms.

Soil samples were collected in every location from the surface layer $(0-20 \mathrm{~cm})$. Combined samples were air-dried and powdered. Electrical conductivity (EC) were measured using CPC-501 conductivity meter and $\mathrm{pH}$ in $\mathrm{KCl}$ with potentiometric method using ion-selective meter UNICAM - 9460 with $\mathrm{pH}$ electrode. In order to determine the total content of heavy metals, soil material was digested using the wet method in a closed system in a microwave oven (Multiwave 3000, Anton Paar). The soil material was treated with a $9 \mathrm{~cm}^{3}$ mixture $(1: 3 \mathrm{v} / \mathrm{v})$ of concentrated acids, $\mathrm{HCl}$ and $\mathrm{HNO}_{3}$ (Suprapur, Merck). Contents of heavy metals were determined using a Perkin-Elmer model Optima 7300 DV inductively coupled plasma atomic emission spectrometer (ICP-A OES). All analysis were done in three replications (from every location five samples were taken, mixed together, and from which three extracts were done).

Chlorophyll $a$ fluorescence was examined using HandyPea fluorimeter (Hanstatech Instruments Ltd. UK) at light intensity of $2500-3000 \mu \mathrm{mol} \cdot \mathrm{m}^{-2} \cdot \mathrm{s}^{-1}$, after 30 minutes long dark adaptation with dark-adapting leaf clips (Hanstatech Instruments Ltd. UK). Content of assimilation pigment (chlorophyll $a, b$ and carotenoids) were analyzed according to Wellburn (1994).

Catalase activity (CAT) was analyzed according to the Bartosz (2006) method by measuring the presence of $\mathrm{H}_{2} \mathrm{O}_{2}$. Soluble peroxidase activity (POD) was determined using the Lück (1962) method, ionically bound peroxidase activity was determined using Syros et al. (2004) method. The activity of superoxide dismutase (SOD) was quantified by the method described by Hwang et al. (1999). Phenolic compounds were analyzed according to Cicco et al. (2009). Radical scavenging activity (against DPPH free radical) was measured with Pekkarinen et al. (1999) method.

Collected, fresh plant material was crushed and then used to prepare samples to further analysis. Weight of the 
samples for enzymes activity analysis, DPPH free radical scavenging activity and phenolics were $0.5 \mathrm{~g}$ each, for chlorophyll and carotenoids about $0.02 \mathrm{~g}$. All plant material analyzes were done in four replications (four different extracts), except for chlorophyll $a$ fluorescence measurements which were done in 10 replications for each object.

Data were analyzed by ANOVA. The significance of differences were determined according to the LSD-Fisher test, with significance $\alpha=0.05$.

\section{Results and discussion}

\subsection{Soil analysis}

The lowest value of soil $\mathrm{pH}_{\mathrm{KCl}}(6.0)$ was noted in the U1 location, which is the home garden (Fig. 1). Slightly acidic condition is considered as optimal for most plants. Highest value of $\mathrm{pH}=7.66$ (alkaline reaction) was measured at the I5 location which is a few-years old waste heap. Other locations showed neutral reaction but it was higher in the I6 (National forests on an old waste heap) than in U2, U3 and $\mathrm{I} 4$ locations. Also values of soil EC was the lowest in $\mathrm{U} 1$ location, and higher for I6, U3 and U2 respectively. The highest values of EC was recorded in soils from Industrial locations I4 and I5 reaching about $2600 \mu \mathrm{S} \cdot \mathrm{cm}^{-1}$.

Polish Ministry of the Environment (2002) elaborates standards specifying critical values for heavy metal content in the soils dividing the soils in three groups. Group A - soils on the areas covered with nature conservation (the most restricted critical values), group B - arable lands, forest lands, fallow lands and build-up areas, group $\mathrm{C}$ - industrial areas, fossil lands and communication areas (highest admissible values). On the figures were presented limits established for groups B and C. Critical values of heavy metals content established by Polish Ministry of the En- vironment was exceeded only for $\mathrm{Cd}, \mathrm{Zn}$ and $\mathrm{Pb}$ in all $\mathrm{In}$ dustrial areas which rise up as the $\mathrm{Zn}-\mathrm{Pb}$ ores mining result (Fig. 2). Values were higher than standards evaluated for urban areas but also for the industrial ones. In the case of $\mathrm{Cd}, \mathrm{Zn}$ and $\mathrm{Pb}$ lowest values in the Industrial areas showed soils from I6 and the highest from I4 location. Highest values of $\mathrm{Cr}$ and $\mathrm{Ni}$ were evaluated in $\mathrm{U} 2$ and highest $\mathrm{Cu}$ in I5 location but for those elements values did not exceed standards in any case. Analysis of results presented on figures 1 and 2 show that the most stressful conditions were present in the I4 location.

\subsection{Plant material analysis}

Chlorophyll $a$ fluorescence parameters are widely used in plant ecophysiological studies. Photosystem II is considered to be highly sensitive to heavy metals pollution. It is reported that metals like lead $(\mathrm{Pb})$, cadmium $(\mathrm{Cd})$ and zinc $(\mathrm{Zn})$ interfere the electron flow at the water-splitting site (Mallick \& Mohn 2003). All of the investigated chlorophyll $a$ fluorescence parameters showed lowest values in the leaves from I4 location (Table 1). It points out that PSII maximum efficiency (Fv/Fm), vitality (PI) and also force absorbed by the reaction center in relation to all absorbed energy ( $\mathrm{RC} / \mathrm{ABS})$ are disturbed in $\mathrm{I} 4$ in relation to other locations. Which corresponds with the highest contamination with $\mathrm{Cd}, \mathrm{Zn}$ and $\mathrm{Pb}$ in this location. What is interesting all chlorophyll $a$ fluorescence parameters for I5 did not differ significantly from U1 and U3 despite quite high contamination $\mathrm{I} 5$ with $\mathrm{Cd}, \mathrm{Zn}$ and $\mathrm{Pb}$.

Decrease in concentration of photosynthetic pigments is considered as good indicator of heavy metal stress. It is known that $\mathrm{Cu}$ and $\mathrm{Zn}$, even before toxic symptoms are observed, can cause pigment decrease (MacFarlane \& Burchett 2001). Chlorophyll content was the lowest in the leaves from I4 and I6 location which may be connected

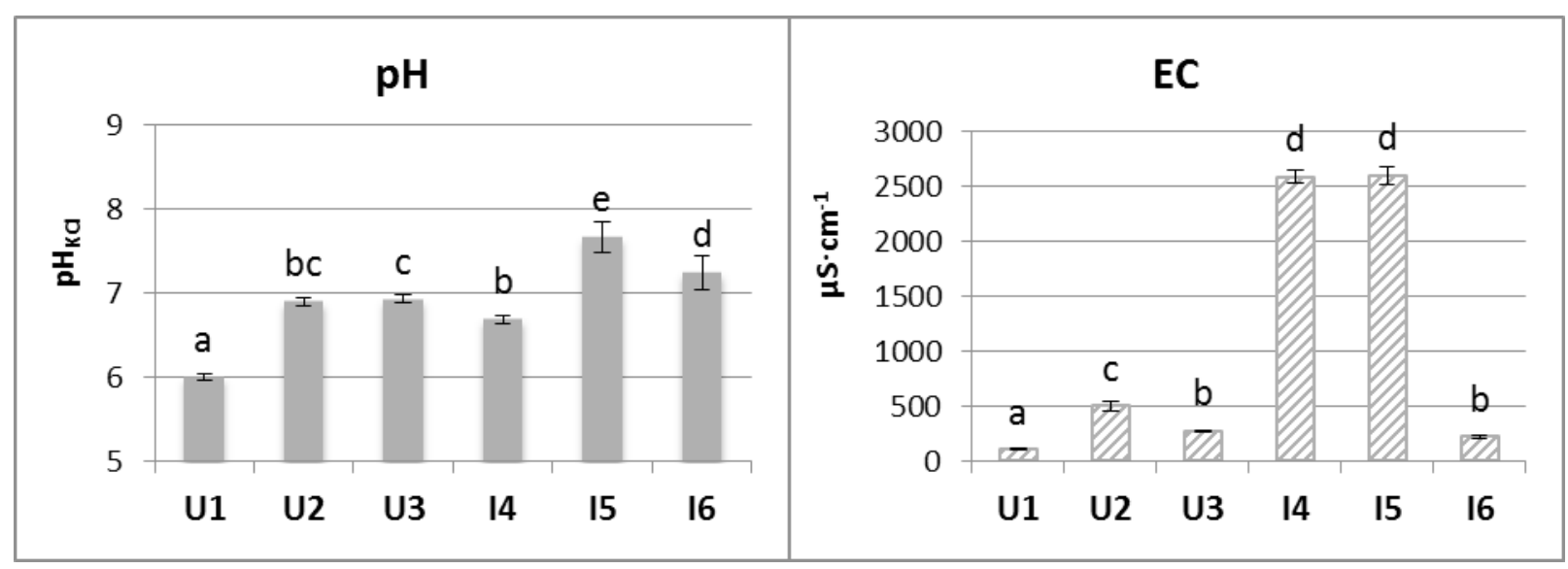

Figure 1. Values of soil $\mathrm{pH}_{\mathrm{KCl}}$ and $\mathrm{EC}\left[\mu \mathrm{S} \cdot \mathrm{cm}^{-1}\right]$ marked for investigated locations. Values marked with the same letters did not differ significantly with $\alpha=0.05$ (Standard deviations are presented as plus/minus error bars) 


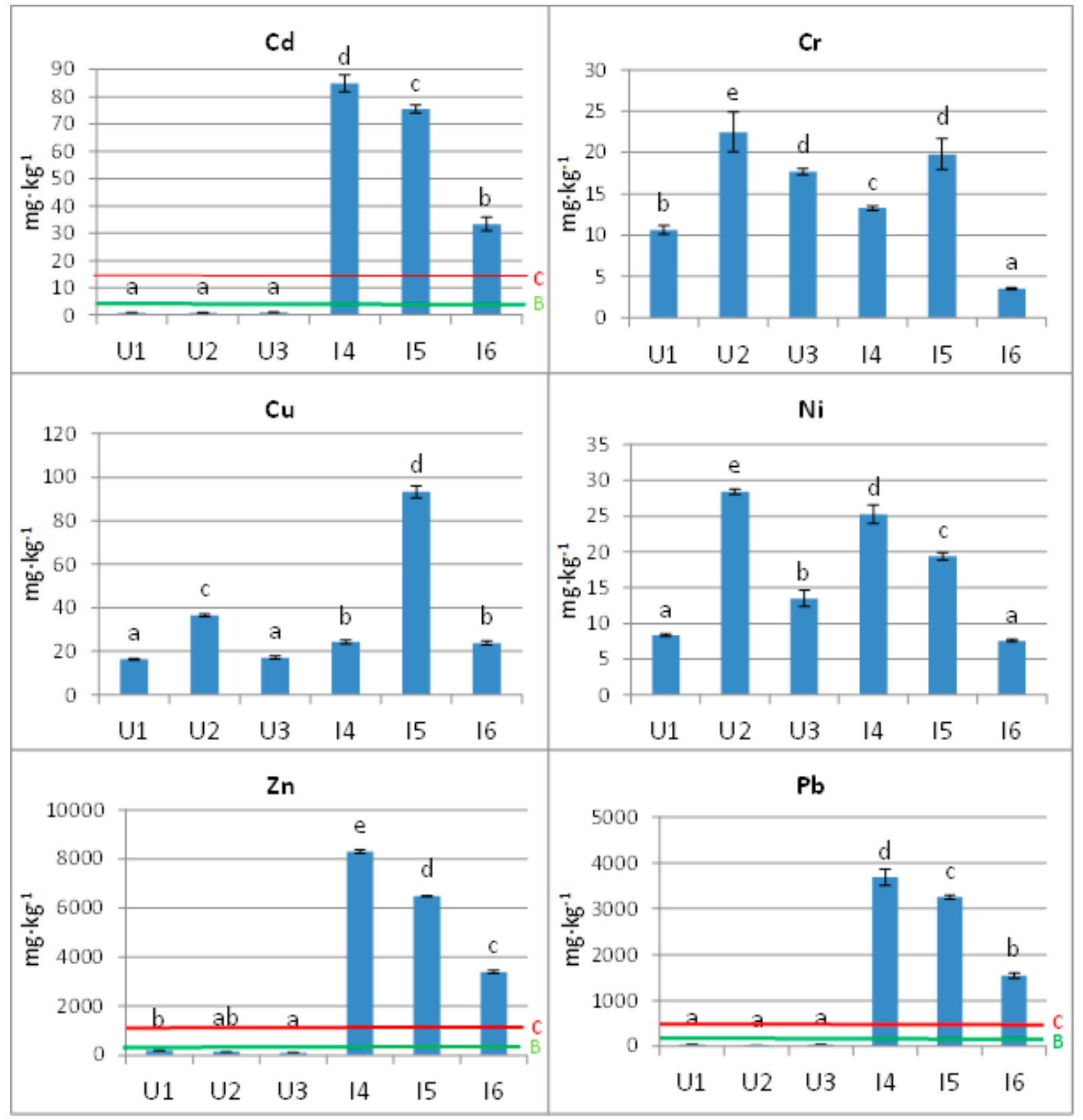

Figure 2. Content of total heavy metals $\left[\mathrm{mg} \cdot \mathrm{kg}^{-1}\right]$ in soils collected from investigated locations. Lines on the figures present limits elaborated by the Polish Ministry of the Environment for B and C groups. Values marked with the same letters did not differ significantly with $\alpha=0.05$ (Standard deviations are presented as plus/minus error bars) 
Table 1. Chlorophyll a fluorescence parameters (Fv/Fm, PI, $\mathrm{RC} / \mathrm{ABS}$ ) measured for investigated objects. Values marked with the same letters did not differ significantly with $\alpha=0.05$

\begin{tabular}{|c|c|c|c|}
\hline location & Fv/Fm & PI & RC/ABS \\
\hline $\mathrm{U} 1$ & $0.852 \mathrm{~b}$ & $4.460 \mathrm{~cd}$ & $1.292 \mathrm{~cd}$ \\
\hline $\mathrm{U} 2$ & $0.856 \mathrm{~b}$ & $3.500 \mathrm{bc}$ & $1.117 \mathrm{bc}$ \\
\hline $\mathrm{U} 3$ & $0.855 \mathrm{~b}$ & $4.746 \mathrm{~d}$ & $1.352 \mathrm{~d}$ \\
\hline $\mathrm{I} 4$ & $0.829 \mathrm{a}$ & $1.674 \mathrm{a}$ & $0.784 \mathrm{a}$ \\
\hline $\mathrm{I} 5$ & $0.848 \mathrm{~b}$ & $4.354 \mathrm{~cd}$ & $1.351 \mathrm{~d}$ \\
\hline $\mathrm{I} 6$ & $0.846 \mathrm{~b}$ & $2.894 \mathrm{~b}$ & $1.024 \mathrm{~b}$ \\
\hline
\end{tabular}

with high stressful conditions (Fig. 3). The highest chlorophyll content was measured in the leaves from U1 and U3 locations. The highest values of carotenoid content was also noted in the leaves from $\mathrm{U} 1$ and $\mathrm{U} 3$.

Concerning low chlorophyll $a$ fluorescence parameters and low pigments concentration as indicators of plant stress, we arrange objects in a sequence from most to less stressed (data not presented). According to the sequence trees from I4 were most stressed, from I6 were the second and the third were trees from U2 location. Less stressed were trees from I5 and U1 locations, and least stressed were trees growing in U3. Which was connected with the soil parameters.

Plants have rich antioxidative system which control level of reactive oxygen species. This system consist enzymatic antioxidants (peroxidase, catalase, superoxide dismutase and others) and low molecular weight antioxidants

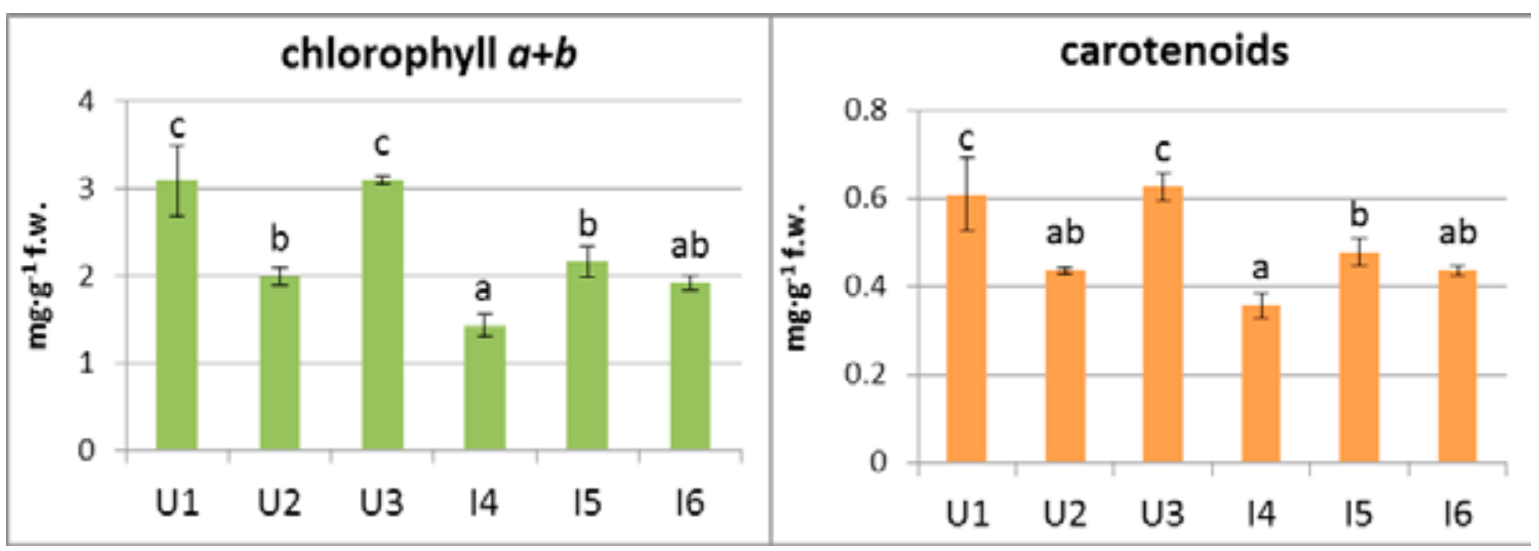

Figure 3. Chlorophyll $a+b$ and carotenoids content $\left[\mathrm{mg} \cdot \mathrm{g}^{-1}\right.$ f.w.] in the leaves of birch collected from six different locations. Values marked with the same letters did not differ significantly with $\alpha=0.05$ (Standard deviations are presented as plus/minus error bars)

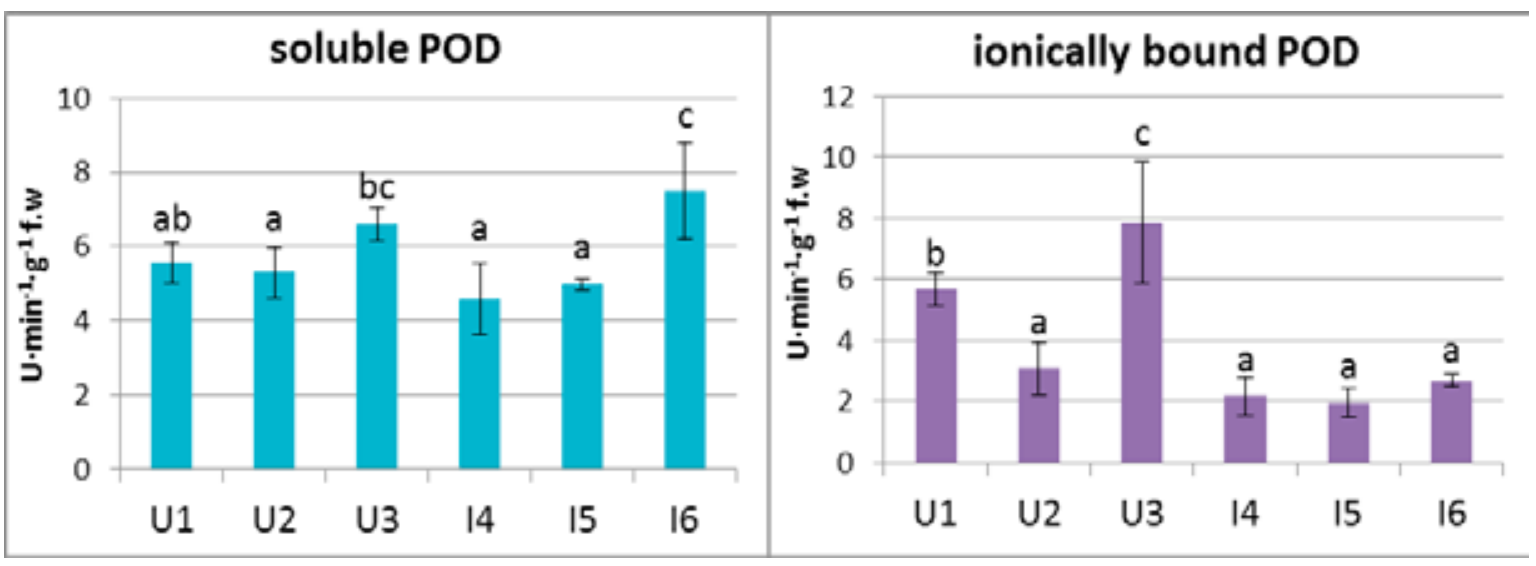

Figure 4. Activity of soluble and ionically bound peroxidase (POD) $\left[\mathrm{U} \cdot \mathrm{min}^{-1} \cdot \mathrm{g}^{-1} \mathrm{f}\right.$.w.] in the leaves of birch collected from six different locations. Values marked with the same letters did not differ significantly with $\alpha=0.05$ (Standard deviations are presented as plus/minus error bars) 


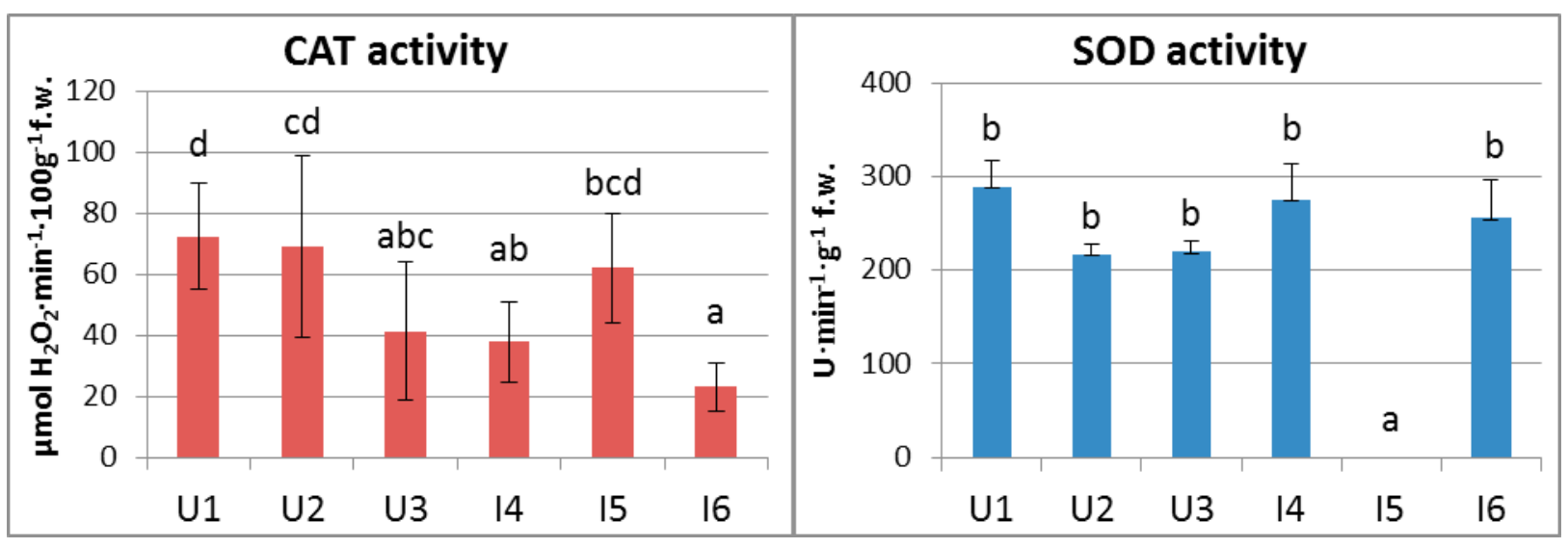

Figure 5. Activity of Catalase (CAT) and Superoxide Dismutase (SOD) in the leaves of birch collected from six different locations. Values marked with the same letters did not differ significantly with $\alpha=0.05$ (Standard deviations are presented as plus/minus error bars)

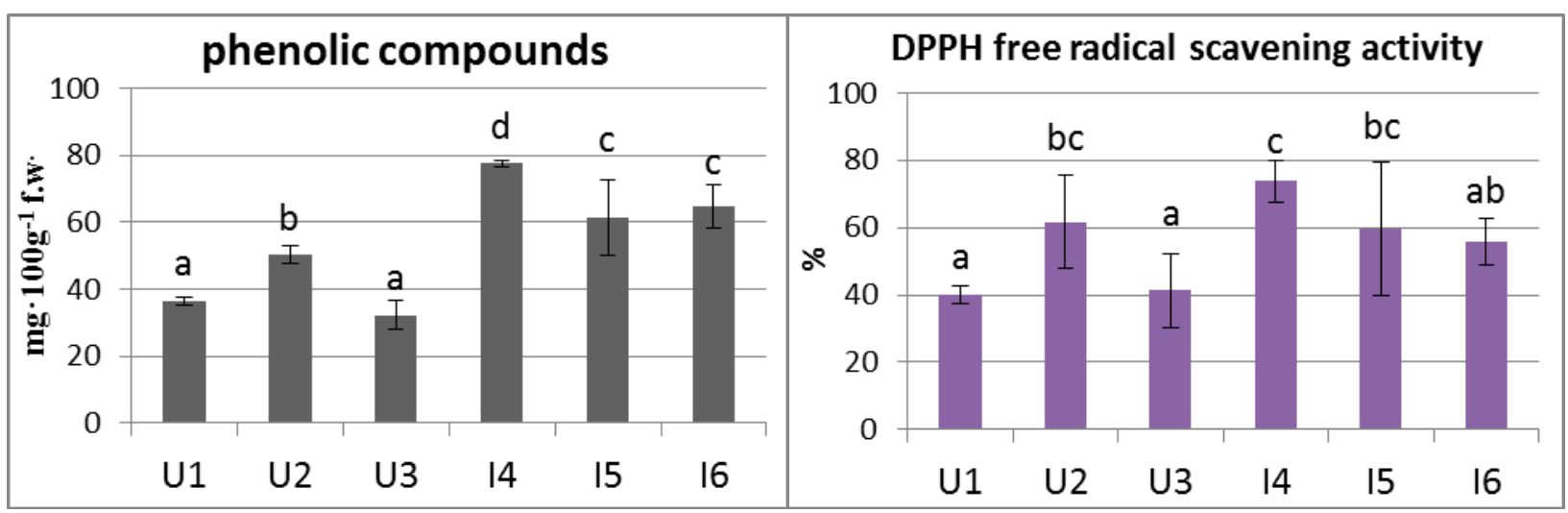

Figure 6. Phenolic compounds and radical scavenging activity (against DPPH free radical) in the leaves of birch collected from six different locations. Values marked with the same letters did not differ significantly with $\alpha=0.05$ (Standard deviations are presented as plus/minus error bars)

(phenolic compounds, ascorbic acid and others) (Bhaduri \& Fulekar 2012). During oxidative stress caused by heavy metals pollution both increase and also decrease of antioxidative elements was observed. Phenolic compounds are important in heavy metals detoxification. They can neutralize some of ROS, chelate heavy metals but also influence antioxidative enzymes activity (mostly peroxidases) (Baranowska-Morek 2003; Michalak 2006). Highest activity of soluble POD was measured in the leaves from I6 location and it did not differ significantly from value measured in leaves from location U3 (Fig. 4). Also highest activity of bonded POD was noted in the leaves from U3 location. What is interesting leaves collected from U2 showed significantly lower activity of bound POD than in other urban locations. U2 location has higher amounts of $\mathrm{Cr}, \mathrm{Cu}$ and $\mathrm{Ni}$ than U1 and U3. One of the main function of peroxidases is being a part of detoxification enzyme complex in the cell wall, which prevents damage during different kinds of stress (Parmar et al. 2002). It is known that heavy metals can affect cell wall in active way (Krzesłowska 2011), therefore they could decrease peroxidases content due to its activation and use to reduction $\mathrm{O}_{2}$.

Catalase activity was the highest in the leaves from U1 and it did not differ significantly from values reached in the leaves from U2 and I5 locations (Fig. 5). For the SOD activity the lowest value was reached for leaves from I5 which where nearly zero, probably due to especially intensive influence of stress factors.

Phenolic compounds concentration showed lowest values in the leaves from U1 and U3 locations and the highest in I4 (Fig. 6). Similarly the lowest free radical scavenging activity was noted in U1. Extracts from leaves collected from U2, I4 and I5 have significantly higher DPPH free radical scavenging activity. 
Such stress induce oxidative stress and immediate plant response. According to given sequence the most stressed trees were those growing in I4 location which is a 100-years old waste heap. Leaves collected from this area show the highest content of phenolic compounds and the highest DPPH scavenging activity.

\section{Conclusions}

The following conclusions can be drawn from the studies:

1. Examined trees showed different groups of reactions to stress factors in the environment of their growth.

2. Trees growing in chosen urban locations showed intensified defense with enzymatic antioxidants while those in industrial areas with low molecular weight antioxidants like phenolic compounds.

3. All of the investigated trees are alive and are coping with stress but in different ways, depending from the intensity of the stress factor.

\section{References}

Appenroth K.J., 2010, What are "heavy metals" in Plant Sciences?, Acta Physiologiae Plantarum 32: 615-619.

Augustynowicz J., Tokarz K., Baran A. \& Płachno B.J., 2014, Phytoremediation of Water Polluted by Thallium, Cadmium, Zinc, and Lead with the Use of Macrophyte Callitriche cophocarpa, Archives of Environmental Contamination and Toxicology 66(4): 572-81.

Babula P., Adam V., Opatrilova R., Zehnalek J., Havel L. \& Kizek R., 2008, Uncommon heavy metals, metalloids and their plant toxicity: a review, Environmental Chemistry Letters 6(4): 189-213.

Baranowska-Morek A., 2003, Roślinne mechanizmy tolerancji na toksyczne działanie metali ciężkich [Plant species mechanisms of tolerance to the toxic effects of heavy metals], Kosmos, Problemy Nauk Biologicznych 52(2-3): 259-260.

Bartosz G., 2006, Druga twarz tlenu: Wolne rodniki w przyrodzie [The other aspect of oxygen: Free radicals in nature], Wydawnictwo Naukowe PWN, Warszawa.

Bhaduri A.M. \& Fulekar M.H., 2012, Antioxidant enzyme responses of plants to heavy metal stress, Reviews in Environmental Science and Biotechnology 11: 55-69.

Carvalho R.F., Monteiro C.C., Caetano A.C., Dourado M.N. \& Gratão P.L., 2012, Leaf senescence in tomato mutants as affected by irradiance and phytohormones, Biologia Plantarum 57(4): 749-757.

Chen Y., Zhang M., Chen T., Zhang Y. \& An L., 2006, The relationship between seasonal changes in anti-oxidative system and freezing tolerance in the leaves of ever- green woody plants of Sabina, South African Journal of Botany 72(2): 272-279.

Cicco N., Lanorte M.T., Paraggio M., Viggiano M. \& Lattanzio V., 2009, A reproducible, rapid and inexpensive Folin-Ciocalteu micro-method in determining phenolics of plant methanol extracts, Microchemical Journal 91: $107-110$.

Hanus-Fajerska E. \& Ciarkowska K., 2010, Phytoextraction of zinc, lead and cadmium from post-flotation tailings using tree clones, Ecological Chemistry and Engineering A, 17(9): 1111-1116.

Hwang S-Y., Lin H-W., Chern R.-H., Feng Lo H. \& Li L., 1999, Reduced susceptibility to waterlogging together with high-light stress is related to increases in superoxide dismutase and catalase activities in sweet potato, Plant Growth Regulation 27: 167-172.

Hortensteiner S. \& Feller U., 2002, Nitrogen metabolism and remobilization during senescence, Journal of Experimental Botany 53(370): 927-937.

Karuppanapandian T., Moon J.C., Kim C., Manoharan K. \& Kim W., 2011, Reactive oxygen species in plants: their generation, signal transduction, and scavenging mechanisms, Australian Journal of Crop Science 5(6): 709-725.

Krzesłowska M., 2011, The cell wall in plant cell response to trace metals: polysaccharide remodeling and its role in defense strategy, Acta Physiologiae Plantarum 33: $35-51$.

Lück H., 1962, Peroxidase, [in:] H.U. Bergmeyer (ed.) Methoden der enzymatischen Analyse, Verlag Chemie, Weinheim: 895-897.

MacFarlane G.R. \& Burchett M.D., 2001, Photosynthetic Pigments and Peroxidase Activity as Indicators of Heavy Metal Stress in the Grey Mangrove, Avicennia marina (Forsk.) Vierh., Marine Pollution Bulletin 42(3): 233-240.

Mallick N. \& Mohn F.H., 2003, Use of chlorophyll fluorescence in metal-stress research: a case study with the green microalga Scenedesmus, Ecotoxicology and Environmental Safety 55: 64-69.

Michalak A., 2006, Phenolic Compounds and Their Antioxidant Activity in Plants Growing under Heavy Metal Stress, Polish Journal of Environmental Studies 14(4): 523-530.

Mmolawa K.B., Likuku A.S. \& Gaboutloeloe G.K., 2011, Assessment of heavy metal pollution in soils along major roadside areas in Botswana, African Journal of Environmental Science and Technology 5(3): 186-196. Muszyńska E., Hanus-Fajerska E. \& Koźmińska A., 2013, Rośliny drzewiaste wykorzystywane w rekultywacji terenów przemysłowych i poprzemysłowych [Woody plants used in restoration of industrial and post-industrial lands], Episteme 21/2013 (1): 397-403. 
Nagajyoti P.C., Lee K.D. \& Sreekanth T.V.M., 2010, Heavy metals, occurrence and toxicity for plants: a review, Environmental Chemistry Letters 8: 199-216.

Parmar N.G., Vithalani S.D. \& Chanda S.V., 2002, Alteration in growth and peroxidase activity by heavy metals in Phaseolus seedlings, Acta Physiologiae Plantarum 24(1): 89-95.

Pekkarinen S.S., Stöckmann H., Schwarz K., Heinonen I.M. \& Hopia A.I., 1999, Antioxidant activity and partitioning of phenolic acids in bulk and emulsified methyl linoleate, Journal of Agricultural and Food Chemistry 47: 3036-3043

Polish Ministry of the Environment, 2002, Rozporządzenie Ministra Środowiska z dnia 9 września 2002 r. w sprawie standardów jakości gleby oraz standardów jakości ziemi. Na podstawie art. 105 ust. 1 ustawy z dnia 27 kwietnia 2001 r. - Prawo ochrony Środowiska (Dz. U. z 2001 r. Nr 62, poz. 627 i Nr 115, poz. 1229 oraz z 202 r. Nr 74, poz. 676, Nr 113, poz. 984 i Nr 153, poz. 1271) [Regulation of the Minister of the Environment of 9 September 2002 on the soil and land quality standards. Pursuant to clause 105, paragraph 1 of the act of 27 April 2001 - Environmental Protection Law (Dz.U. of 2001 No. 62, item 627 and No. 115, item 1229 and of 2002 No. 74, item 676, No. 113, item 984 and No. 153, item 1271)], Warszawa.
Syros T., Yupsanis T., Zafiriadis H. \& Economou A., 2004, Activity and isoforms of peroxidases, lignin and anatomy, during adventitious rooting in cuttings of Ebenus cretica L, Journal of Plant Physiology 161: 69-77.

Wellburn A.R., 1994, The spectral determination of chlorophylls $a$ and $b$, as well as total carotenoids, using various solvents with spectrophotometers of different resolution, Journal of Plant Physiology 144: 307-313.

Zhang H. \& Zhou C., 2013, Signal transduction in leaf senescence, Plant Molecular Biology 82(6): 539-45.

Žibret G., Van Tonder D. \& Žibret L., 2013, Metal content in street dust as a reflection of atmospheric dust emissions from coal power plants, metal smelters, and traffic, Environmental Science and Pollution Research International 20(7): 4455-4468.

Zvereva E.L., Toivonen E., \& Kozlov M.V., 2008, Changes in species richness of vascular plants under the impact of air pollution: a global perspective, Global Ecology and Biogeography 17(3): 305-319. 